\title{
Two different mechanisms in patients with venous thrombosis and defective fibrinolysis: low concentration of plasminogen activator or increased concentration of plasminogen activator inhibitor
}

\author{
INGA MARIE NILSSON, HARALD LJUNGNER, LILIAN TENGBORN
}

\begin{abstract}
Fibrinolytic components after venous occlusion and concentrations of tissue plasminogen activator inhibitor were studied in 100 consecutive patients with confirmed recurrent deep vein thrombosis or pulmonary embolism. After 20 minutes of venous occlusion the fibrinolytic response was decreased in 33 patients, as measured both amidolytically with $\mathrm{S}-2251$ and on fibrin plates. Two different mechanisms responsible for the poor fibrinolytic response could be distinguished. Twenty two of the patients in whom the response was poor released normal amounts of tissue plasminogen activator antigen, as assayed by immunoradiometric assay, but had appreciably increased concentrations of tissue plasminogen activator inhibitor. The 11 other patients in whom the response was poor had both low tissue plasminogen activator activities and low tissue plasminogen activator antigen concentrations but normal concentrations of tissue plasminogen activator inhibitor.

The results show not only that defective synthesis or release of tissue plasminogen activator may be important in the pathogenesis of venous thrombosis but also that a large group of patients with thrombosis have an increased concentration of the inhibitor to tissue plasminogen activator.
\end{abstract}

\footnotetext{
Department for Coagulation Disorders, University of Lund, General Hospital, S-214 01 Malmö, Sweden

INGA MARIE NILSSON, MD, professor

LILIAN TENGBORN, MD, senior physician

Department of Surgery, University of Lund

HARALD LJUNGNÉR, MD, senior physician

Correspondence to: Dr I M Nilsson.
}

\section{Introduction}

In the complex pathogenesis of venous thrombosis one important factor promoting the development of venous thrombosis is a defective fibrinolytic system. This system is activated by various agents, an important one being the tissue type plasminogen activator, localised to the vessel wall. It is well known that many patients with recurrent idiopathic venous thrombosis have defective fibrinolytic systems-that is, decreased vessel wall fibrinolysis or defective release of activators after venous occlusion tests, or both. ${ }^{1-8}$

The role of fibrinolytic inhibitors in association with venous thrombosis was first described in $1961 .{ }^{9}$ Since then several studies have dealt with different inhibitors and their role in the disease.

A new rapid inhibitor to tissue plasminogen activator has been identified, ${ }^{10-13}$ but its physiological importance in patients with thrombosis is less well understood. We aimed therefore to study both the fibrinolytic components in postocclusion plasma and the tissue plasminogen activator inhibitor in patients with recurrent deep venous thrombosis.

\section{Subjects and methods}

We studied 60 men and 40 women, aged 14-70 (mean 43) years, who had been referred because of recurrent deep venous thrombosis or pulmonary embolism without any other known diseases. All the patients were investigated at least three months after their latest thrombotic episode. Diagnosis was always verified by phlebography or pulmonary scintigraphy and angiography. At the time of investigation 73 of the patients were taking vitamin $\mathrm{K}$ antagonists.

Fifty seven volunteers (policemen, doctors, nurses, office workers, mechanics, and technicians) aged 20-60 (mean 33) years, of whom 27 were women, served as controls. All were apparently healthy, and none had any history of superficial thrombophlebitis, deep venous thrombosis, or any other disease in which thrombosis is commonly a complicating factor. None of the female controls was taking a contraceptive drug. Controls and patients were studied in parallel. 


\section{COLLECTION OF BLOOD}

Citrated, platelet poor plasma was prepared as previously described. ${ }^{14}$ For the fibrin plate assay the plasma samples were not frozen but tested immediately, other samples being stored at $-80^{\circ} \mathrm{C}$ until use. The samples for assay of tissue plasminogen activator by chromogenic substrate were kept on ice, centrifuged at $0^{\circ} \mathrm{C}$ without delay, and frozen rapidly. For immunoradiometric measurement of tissue plasminogen activator blood was collected in edetic acid $(0.38 \mathrm{~mol} / 1$ $(11 \mathrm{~g} / 100 \mathrm{ml})$ ) at a ratio of nine to one.

\section{VENOUS OCCLUSION TEST}

Venous occlusion was achieved by applying a sphygmomanometer cuff around each arm and inflating the cuffs to maintain a pressure midway between the systolic and diastolic pressures for 20 minutes. $^{15}$ Blood samples for measuring the released plasminogen activators were drawn, from an antecubital vein, immediately before the cuffs were applied and again immediately before they were deflated. The mean increase in plasminogen activators in the samples from each arm was calculated.

\section{COAGULATION AND FIBRINOLYTIC STUDIES}

The following variables were determined: platelet count; automated activated partial thromboplastin time (APTT; General Diagnostics, New Jersey); one stage prothrombin time; prothrombin, factor VII, and factor X concentrations (Owren's method); factor V concentration; fibrinogen concentration; thrombin time; reptilase time; factor VIII clotting activity; and factor VIII related antigen. The methods have been described elsewhere. ${ }^{14} 16$ Plasminogen was measured both by radioimmunodiffusion (own antiserum) and amidolytically with S-2251 (KabiVitrum AB; Sweden). ${ }^{17}$ Antithrombin III was assayed by electroimmunoassay ${ }^{18}$ and amidolytically with S-2238 (KabiVitrum AB, Sweden). ${ }^{19} \alpha_{2}$ Antiplasmin was assayed amidolytically with $\mathrm{S}-2251 .^{20}$ Protein $\mathrm{C}$ was assayed by a semiquantitative immunochemical method ${ }^{21}$ with own antiserum.

\section{DETERMINATION OF PLASMINOGEN ACTIVATORS}

The plasminogen activators released during venous occlusion were studied using three different methods. As standard for the assays we used human tissue plasminogen activator (NIBSC reagent 83/517), and results were expressed as $\mathrm{U} / \mathrm{ml}$

(1) The fibrin plate method ${ }^{22}$-Plasminogen rich human fibrinogen (KabiVitrum AB; Stockholm) was used. Undiluted citrated plasma was deposited directly on the fibrin plates in aliquots of $0.03 \mathrm{ml}$ in triplicate, and the plates were incubated at $37^{\circ} \mathrm{C}$ for 20 hours. The lytic zones were recorded as follows: two perpendicular diameters of the lysed areas were measured $(\mathrm{mm})$, the readings multiplied by each other, and the square root calculated.

(2) Tissue plasminogen activator $(S-2251)$-Tissue plasminogen activator was measured amidolytically according to the method of Gyzander et al. ${ }^{23}$ The tissue plasminogen activator and plasminogen in the sample were adsorbed to lysine sepharose. The lysine sepharose was then mixed with glu-plasminogen, poly-D-lysine, and S-2251, and the absorbance was read.

(3) Tissue plasminogen activator antigen-Tissue plasminogen activator substance was analysed by immunoradiometric assay as described by Holmberg et al. ${ }^{24}$ Purified antibodies to melanoma activator were prepared as described by Wallén et $a l^{25}$ and radiolabelled with iodine- 125 by the lactoperoxidase method. The assay was performed as a two side phase assay in polystyrene tubes.

\section{MEASUREMENT OF TISSUE PLASMINOGEN ACTIVATOR INHIBITORS}

The rapid tissue plasminogen activator inhibitor was measured by adding $10 \mathrm{ng}$ purified melanoma activator (LBK 66; KabiVitrum $\mathrm{AB}$, Sweden: $1 \mathrm{ng}$ contains $1 \mathrm{U}$ tissue plasminogen activator) per $\mathrm{ml}$ plasma in various dilutions $(1: 1,1: 2,1: 5,1: 10$, and $1: 20)$. After incubation for 15 minutes at $37^{\circ} \mathrm{C}$ residual activator activity was measured with $\mathrm{S}-2251$ as described above. Inhibitor activity was expressed in units, one inhibitor unit being defined as the amount required to neutralise $1 \mathrm{U}$ tissue plasminogen activator. The tissue plasminogen activator inhibitor was always determined in samples taken before venous occlusion.

\section{STATISTICAL METHODS}

The Mann-Whitney rank sum test for unpaired observations was used to assess significance of difference, the level of significance chosen being $\mathrm{p}<0.05$.

\section{Results}

All patients had normal platelet counts, activated partial thromboplastin times, one stage prothrombin times, factor $\mathbf{V}$ concentrations, factor VIII clotting activities, factor VIII related antigen concentrations, thrombin times, reptilase times, plasminogen concentrations, antithrombin III concentrations, $\alpha_{2}$ antiplasmin concentrations, and protein $\mathrm{C}$ concentrations.

The table shows the range and mean values of fibrinolytic variables in the controls. Tissue plasminogen activator values determined amidolytically showed wide variation in controls, as reported previously. ${ }^{26}$ The concentration of the tissue plasminogen activator inhibitor was consistently less than $11 \mathrm{U} / \mathrm{ml}$.

Mean (SD) [range] values of fibrinolytic components after venous occlusion and tissue plasminogen activator $(t-P A)$ before venous occlusion in 100 patient with recurrent deep venous thrombosis or pulmonary embolism and 57 controls. (Patients divided into groups on basis of results)

\begin{tabular}{|c|c|c|c|c|}
\hline & \multirow{2}{*}{$\begin{array}{l}\text { Controls } \\
(n=57)\end{array}$} & \multicolumn{3}{|c|}{ Patients } \\
\hline & & $\begin{array}{l}\text { Group 1 } \\
(n=67)\end{array}$ & $\begin{array}{l}\text { Group } 2 \\
(\mathrm{n}=22)\end{array}$ & $\begin{array}{c}\text { Group } 3 \\
(n=11)\end{array}$ \\
\hline $\begin{array}{l}\text { Fibrin plates }(\mathrm{mm}) \\
\text { t-PA S-2251 }(\mathrm{U} / \mathrm{ml}) \\
\text { t-PA antigen }(\mathrm{U} / \mathrm{ml}) \\
\text { t-PA inhibitor }(\mathrm{U} / \mathrm{ml})\end{array}$ & $\begin{array}{c}18(5) \\
{[8 \cdot 4-21 \cdot 9]} \\
18(12) \\
{[4-47]} \\
15(10) \\
{[4 \cdot 9-37]} \\
8(2) \\
{[4 \cdot 7-11]}\end{array}$ & $\begin{array}{l}18(4) \\
{[9 \cdot 7-22 \cdot 6]} \\
23(18) \\
{[5 \cdot 7-59]} \\
20(11) \\
{[2 \cdot 8-61]} \\
8(3) \\
{[1-16]}\end{array}$ & $\begin{array}{l}4(4) \\
{[0-12 \cdot 1]} \\
1(1) \\
{[0-4 \cdot 2]} \\
22(11) \\
{[10-75]} \\
45(20) \\
{[17-109]}\end{array}$ & $\begin{array}{c}6(4) \\
{[0-11 \cdot 7]} \\
1(1) \\
{[0 \cdot 1-4 \cdot 1]} \\
2(1) \\
{[1 \cdot 9-7 \cdot 6]} \\
7(4) \\
{[2 \cdot 5-14]}\end{array}$ \\
\hline
\end{tabular}

Our patients with venous thrombosis could be divided into three groups (table). The first (group 1) consisted of 67 patients, all of whom had normal tissue plasminogen activator values after the venous occlusion test as determined on fibrin plates, amidolytically, and by immunoradiometric assay. The concentration of the inhibitor to tissue plasminogen activator was also within the normal range except in one patient, who had a slightly increased concentration.

A defective fibrinolytic system was found in 33 patients $(33 \%)$ and two different groups could be distinguished. One group (group 2) comprised 22 patients all with normal concentrations of released tissue plasminogen activator antigen after venous occlusion as measured by immunoradiometric assay but poor response when determined either on fibrin plates or amidolytically with S-2251. These patients had significantly $(p<0.005)$ increased concentrations of tissue plasminogen activator inhibitor, which in three patients was seven to 10 times higher than that of normal plasma. In most patients the inhibitor concentration was checked at least twice and was consistently high.

The remaining group (group 3) consisted of 11 patients all with low concentrations of released tissue plasminogen activator after venous occlusion as measured by functional tests (fibrin plates and S-2251). In contrast with patients in group 2 patients in group 3 also had low values for released tissue plasminogen activator as measured by immunoradiometric assay. The values for tissue plasminogen activator antigen differed significantly $(p<0.01)$ from those for patients in group 2. All but one patient in group 3 had values within the normal range for the tissue plasminogen activator inhibitor.

The ages of the patients in group 1 varied between 14 and 67 (mean 41) years, in group 2 between 30 and 73 (mean 53) years, and in group 3 between 15 and 72 (mean 35 ) years. The difference in mean age between groups 2 and 3 was significant $(p<0.001)$, the lower age in group 3 being the only difference noted in clinical pattern between the three groups.

\section{Discussion}

The main source of tissue plasminogen activator is known to be the blood vessels, ${ }^{27} 28$ where endothelial cells both synthesise and store these activators. ${ }^{29} 30$ Furthermore, the activators are 
continuously released from the endothelial cells into the blood stream. ${ }^{27} 29$ Several workers have now shown that patients with impaired fibrinolysis are more susceptible to thrombosis. ${ }^{1}{ }^{2}:$ In principle, defective fibrinolysis might be due to: (1) a decreased synthesis of vessel wall tissue plasminogen activator or defective release of activators, or both; or (2) inactivation of tissue plasminogen activator by inhibitors. Human placenta is known to contain an inhibitor of both urokinase and tissue plasminogen activator. ${ }^{31}$ 3.2 Recently, several groups have reported evidence for the existence of a rapidly acting inhibitor of tissue plasminogen activator in plasma. ${ }^{11-13} 33 \cdots 36$ Interestingly, inhibitors of tissue plasminogen activator have been identified in mediums from bovine, porcine, and human vascular endothelial cells. ${ }^{1219}$ 3:-39 Moreover, evidence has been obtained that the inhibitor in the endothelial cells is present in the culture medium as a complex between tissue plasminogen activator and the inhibitor, having molecular weights of about 95000 and $100000 .^{12} 3^{9}$ The inhibitor has not yet been characterised, but its molecular weight has been calculated to be about $40000.1213^{39} \mathrm{It}$ is not yet known whether the vascular inhibitor is identical with the placenta inhibitor.

The ascertainment of the role of this inhibitor to tissue plasminogen activator present in the vascular endothelium and the plasma in regulating the fibrinolytic activity in the vessel wall and in blood is thus of the utmost interest. Hitherto only a few clinical studies have been published. Wijngaards and Groeneveld and Juhan-Vague et al found increased concentrations of tissue plasminogen activator inhibitor in some severely ill patients with varying diagnoses. ${ }^{34}{ }^{35}$ Recently Wiman et al reported that eight of 24 patients with venous thrombosis had increased concentrations of tissue plasminogen activator inhibitor. "In a large family with a high incidence of venous thrombosis associated with impaired fibrinolysis Nilsson and Tengborn reinvestigated two of the members. ${ }^{36}$ After venous occlusion both showed a normal release of tissue plasminogen activator antigen but low tissue plasminogen activator concentrations as measured by fibrin plates and S-2251. Their plasma contained 50 times more tissue plasminogen activator inhibitor than does normal plasma.

In the present study of 100 consecutive patients with recurrent deep venous thrombosis or pulmonary embolism, or both, the fibrinolytic response after 20 minutes of venous occlusion was decreased in 33, a somewhat lower incidence than in our earlier studies. ${ }^{11}$ That the mean age of our control group was 10 years lower than that of the thrombotic patients was probably immatcrial as no clear relation has been shown between age and ibrinolysis." None of the patients had any abnormalities in concentrations of antithrombin III or protein $\mathrm{C}$, two factors known to predispose to venous thrombosis. ${ }^{43}: 4$

Interestingly, two different mechanisms responsible for the poor fibrinolytic response could be distinguished. After venous occlusion one group of the poor responders (11 patients) had low values for both tissue plasminogen activator activity and tissue plasminogen activator antigen concentration and normal or near nornial concentrations of tissue plasminogen activator inhibitor. Thus this group appeared to have true defective synthesis or release, or both, of tissue plasminogen activator. The other, larger group (22 patients) released normal amounts of tissue plasminogen activator antigen but had appreciably increased concentrations of tissue flasminogen activator inhibitor. These results provide further evidence for the role of the tissue plasminogen activator inhibitor in the pathogenesis of venous thrombosis.

That two diffeient aetiological mechanisms have been found in patiints with defective fibrinolysis may have clinical implications. Tissue type plasininogen activator, produced by recombinant deoxyribonucleic acid technology, ${ }^{45}$ is supposed to be the ti:rombolytic agent of choice in the future. The necessary doses can be expected to depend on the concentration of tissue plasminogen activator inhibitor. To prevent further thrombotic episodes in patients with high inhibitor concentrations the aim must be to find a form of treatment that will reduce the inhibitor concentration. Sue-Ling et al and Verheijen et al have preliminarily reported that administration of the anabolic steroid stanozolol can cause a decrease in the fast acting tissue plasminogen activator inhibitor. ${ }^{16}$ ": : The patients in their studies, however, did not have increased inhibitor concentrations. A study of whether stanozolol has any effect in patients with high inhibitor concentrations would be interesting.

Apart from the lower mean age of patients in group 3 no clinical differences were found between the two groups with poor fibrinolytic response.

To conclude, two different mechanisms may cause defective fibrinolysis in patients with venous thrombosis. Thus important factors include not only defective synthesis and release of tissue plasminogen activator but also an increased concentration of the inhibitor against tissue plasminogen activator.

This study was supported by grants from the Swedish Medical Research Council (00087).

\section{References}

1 Isacson S, Nilsson IM. Defective fibrinolysis in blood and vein walls in recurrent "idiogathic" venous thrombosis. Acta Chir

2 Johansson L, Hedner U, Nilsson IM. A family with thromboembolic disease associated with

3 Sundqvist S-B, Hedner U, Kullenberg HKE, Bergentz S-E Deep venous thrombosis of the arm: a study of coagulation and fibrinolysis. $B r$ Med 3 $1981 ; 283: 265-7$.

4 Liungnér $H$, Bergqvist $D$, Isacson $S$. Plasminogen activator activity of superficial veins in acute deep venous thrombosis. Vasa 1982;11:174-7.

5 Conard J, Veuillet-Duval A, Horellou MH, Samama M. Étude de la coagulation et de la fibrinolyse dans 131 cas de thromboses veineuses récidivantes. Nour Rev Fr Hematol 1982;24:205-9.

6 Stormorken $\mathrm{H}$, Lund $\mathrm{M}$, Holmsen I. Vessel wall activator (t-PA) as evaluated by poststatis euglobulin lysis time (PELT) in recurrent deep vein thrombosis. In: Jespersen J, Kluft C, Korsgaard O, eds. Clinical aspects of fibrinolysis and thrombolysis. Esbierg: South Jutland University Press, 1983:293-309. with red M, Mortensen J., Madsen AG, Thorsen S, Jacobsen B. A family with reduced plasminogen activator activity in blood as
venous thrombosis. Scand $\mathcal{H}$ Haematol $1982 ; 29: 217-23$.

8 Stead NW, Bauer KA, Kinney TR, et al. Venous thrombosis in a family with defective release of vascular plasminogen activator and elevated plasma factor VIII von Willebrand's factor. Am 7 M I ed 1983;74:33-9.

9 Nilsson IM, Krook H, Sternby N-H, Söderberg E, Söderström N. Severe thrombotic disease in a young man with bone marrow and skeletal changes and with a high content of an inhibitor in the fibrinolytic system. Acta Mled Scand 1961;169:323-37

10 Levin EG, Loskutoff DJ. Comparative studies of the fibrinolytic activity of cultured vascular cells. Thromb Res 1979;15:869-78.

1 Chmielewska J, Ranby $M$, Wiman B. Evidence for a rapid inhibitor to tissuc plasminogen activator in plasma. Thromb Res 1983;31:427-36.

12 Philips $M$, Thorsen $S$. Binding of plasminogen activator (PA) to a component (X) of endothelial cells (EC) may explain the 95.000- $\mathrm{N}_{\mathrm{r}} \mathrm{PA}$ in human plasma (abstract). Thromb Haemost $1983 ; \mathbf{5 0}: 193$.
[ats

13 Kruithof EKO, Ransijn A, Tran-Thang $\dot{C}$, Bachmann $F$. Characteristics of a fast acting inhibitor of plasminogen activator in human plasma [abstract]. Thromb Haemost 1983;50:193.

14 Nilsson IM. Haemorrhagic and thrombotic diseases. London: Wiley, 1974

5 Robertson BR, Pandolfi M, Nilsson IM. "Fibrinolytic capacity" of health volunteers as estimated from effect of venous occlusion of arms. Acta Chir Scand 1972;138:429-36.

16 Holmberg L, Nilsson IM. Two riberger $P$ Knöos M Plasminogen determination in human plasma In Scully MF, Kakkar VV, eds. Chromogenic peptide substrates: chemistry and clincical usage. London: Churchill Livingstone, 1979:128-39.

18 Hedner $U$, Nilsson IM. Antithrombin III in a clinical nuaterial. Thromb Res $1973 ; 3: 631-41$

19 Odegárd OR, Lie M, Abildgaard U. Heparin cofactor activity measured with an amidolytic method. Thromb Res $1975 ; 6: 287-94$

20 Teger-Nilsson AC, Friberger P, Gyzander E. Determination of a new rapid antiplasmin in human blood by using a plasmin specific tripeptide substrate. Scand J Clin Lab Imrest 1977;37:403-9.

21 von Schwink HG, Störiko K, Becker W. Quantitative plasmaproteinhestimmung durch Immunoprezipitation. Labor

ilsson IM. Olow B. Fibrinolysis induced by streptokinase in man. Acta Chir Siand $1962: 123: 247-66$

23 Gyzander E, Eriksson E, Teger-Nilsson AC. Determination of tissue plasminogen activator in plasma after adsorption on lysine sepharose. In: Davidson $\mathrm{JF}$, Bachmann F, Bouvier CA, Kruithof EKO, eds. Progress in fibrinolysis. Vol 6 . London: Churchill Livingstone, 1983:425-31.

24 Holmberg L, Nilsson IM, Wallén P, Astedt B. Studies of the blood plasminogen activator induced by 1-desamino-8-D arginine vasopressin with observation in von W'illebrand's discasc. Proc Soc Fxp Biol Med 1982;170:126-32.

25 Wallen P, Ranby M, Bergsdorf N, Kok P. Purification and characterization of tissue activator: on the occurrence of two different forms and their cnzymatic properties. In: Davidson J F, Nilsson IM, Astedt B,

26 Teger- vilsson AC, de Carbonnieres C, Conard J, et al. Determination of tissuc plasminogen activator in patients with thromboembolic tendencr. In plasminogen activator in patients with thrombospects of fibrinclysis and thrombolysis. Esbjerg: South Jutland University Press, 1983:105-17.

27 Rijken DC, Wijngaards $G$, Welbergen J. Relationship between tissue plasminogen activator and the activators in blood and vascular wall. Thromb Res 1980;18: 815-30.

28 Ljungner H, Holmberg L, Kjeldgaard A, Nilsson I.M, stedt AB. Immunological characterisation of plasminogen activators in the human vessel wall. $\mathcal{F}$ Clin

29 Astedt B, Pandolfi $M$. On release and synthesis of fibrinolytic activators in human organ culture. Eurnpean fournal of Clinical and Biological Research 
30 Loskutoff DJ, Edgington T. Synthesis of a fibrinolytic activator and inhibitor by endothelial cells. Proc Natl Acad Sci USA 1977;74:3903-7.

31 Holmberg L, Lecander I, Persson B, Astedt B. An inhibitor from placenta pecifically binds urokinase and inhibits plasminogen activator released from ovarian carcinoma in tissue culture. Biochim Biophys Acta 1978;544:128-37.

32 Lecander I, Roblin R, Astedt B. Differential inhibition of two molecular form of melanoma cell

33 Verheijen JH, Chang GTG, Kluft C. Evidence for the occurrence of a fast-acting inhibitor for tissue-type plasminogen activator in human plasma. Thromb Haemost $1984 ; 51: 392-5$.

34 Juhan-Vague I, Moerman B, De Cock F, Aillaud MF, Collen D. Plasma levels of a specific inhibitor of tissue-type plasminogen activator (and urokinase) in Thromb Res $1984 ; 33: 523-30$

35 Wijngaards G, Groeneveld E. Temporarily increased inhibition by plasma of lasminogen activator activity in severely ill patients [abstract]. Haemostasis $982 ; 12: 106$.

36 Nilsson IM, Tengborn L. Impaired fibrinolysis. New evidence in relation to thrombosis. In: Jespersen J, Kluft C, Korsgaard O, eds. Clinical aspects of fibrinolysi

37 Loskutoff DJ, van Mourik JA, Erickson LA, Lawrence D. Detection of an unusually stable fibrinolytic inhibitor produced by bovine endothelial cells. Proc Natl Acad Sci USA 1983;80:2956-60.

38 Emeis $\mathrm{JJ}$, van Hinsbergh VWM, Verheijen JH, Wijngaards G. Inhibition of tissue-type plasminogen activator by conditioned medium from cultured human and porcine vascular endothelial cells. Biochem Biophys Res Commun 1983;110:392-8.

Levin EG. Latent tissue plasminogen activator produced by human endothelial cells in culture: evidence for an enzyme-inhibitor complex. Proc Natl Acad

40 Wiman B, Ljungberg B, Chmielewska J Urden G, Blombäck M The role of the Thrinolytic system in deep venous thrombosis [abstract]. Haemostasis 1984 ; 14:175.

41 Nilsson IM. Coagulation, fibrinolysis and venous thrombosis. Triangle 1977 16:19-27.

42 Rosing DR, Redwood DR, Brakman P, Astrup T, Epstein SE. Impairment of the diurnal fibrinolytic response in man. Effects of aging, type IV hyperCirc Res $1973 ; 32 \cdot 752-8$. Semin Thromb Hemost 1982; 8:276-8

Griffin JH. Clinical studies of protein C. Semin Thromb Hemost 1984;10:162-6. Pennica D, Holmes WE, Kohr WJ, et al. Cloning and expression of human tissue-type plasminogen activator cDNA in E coli. Nature 1983;301:214-2 HM, Davies JA, McMahon MJ, et al. Indicators of depressed fibrinolytic activity in predictio

47 Verheijen JH, Rijken DC, Chang GTG, Preston FE, Kluft C. Modulation of rapid plasminogen activator inhibitor in plasma by Stanozolol. Thromb Haemost 1984;51:396-7.

\title{
Platelet immune complex interaction in pathogenesis of Kawasaki disease and childhood polyarteritis
}

\author{
MICHAEL LEVIN, PHILIP C HOLLAND, TIM J C NOKES, VALERIO NOVELLI, \\ MARTIN MOLA, ROLAND J LEVINSKY, MICHAEL J DILLON, T MARTIN BARRATT, \\ WILLIAM C MARSHALL
}

\begin{abstract}
The role of platelets in the pathogenesis of vasculitis and the formation of coronary artery aneurysms was studied in 19 children with Kawasaki disease and five with polyarteritis. All patients with Kawasaki disease developed thrombocytosis in the third week of illness. The peak platelet count was significantly correlated $(p<0.005)$ with the subsequent development of coronary artery aneurysms. The rise in platelet count was associated with the appearance in the circulation of a factor that induced aggregation and serotonin release in normal platelets. This factor was shown to be of high molecular weight, and its activity was lost at low pHfeatures suggestive of an immune complex. Immune complexes, detected by precipitation with polyethylene glycol, also appeared in the circulation as the platelet count increased. These complexes induced platelet aggregation, and there was a significant correlation $(p<0.001)$ between the concentrations of IgG and IgA in the polyethylene glycol precipitated material and the platelet aggregating activity. Similar platelet aggregating
\end{abstract}

Departments of Nephrology, Immunology, Haematology, and Infectious Disease, The Hospital for Sick Children, London, and the Institute of Child Health, London

MICHAEL LEVIN, MRCP, lecturer in paediatric nephrology

PHILIP C HOLLAND, MRCP, research fellow

TIM J C NOKES, FIMLS, senior medical laboratory scientific officer

VALERIO NOVELLI, MRCP, research fellow

MARTIN MOLA, MD, research fellow

ROLAND J LEVINSKY, FRCP, reader in immunology

MICHAEL J DILLON, FRCP, consultant paediatric nephrologist

T MARTIN BARRATT, FRCP, professor of paediatric nephrolog

WILLIAM C MARSHALL, FRACP, senior lecturer in infectious disease

(Dr Marshall died in 1983)

Correspondence to: Dr M Levin, Department of Nephrology, Institute of Child Health, London WC1N 1EH. activity was also detected in patients with polyarteritis but followed a different time course, persisting in the circulation for several months in association with continued disease activity.

These findings imply that different mechanisms have a role in distinct phases of Kawasaki disease. The initial feverish phase (probably infective) is probably followed by an immune complex vasculitis that occurs when antibodies to the initiating agent appear in the circulation. The immune complexes aggregate platelets and induce release of serotonin. Platelet derived vasoactive mediators may increase vascular permeability and facilitate further deposition of complexes in the tissues.

\section{Introduction}

Kawasaki disease, or the mucocutaneous lymph node syndrome, is an acute, feverish illness affecting young children, with prominent mucocutaneous and cardiovascular manifestations. Since its description in 1967 many thousands of cases have been seen in Japan, and the disease is recognised increasingly often in many other countries. ${ }^{2}{ }^{3}$

Kawasaki disease is often a benign and self limited illness. Arteritis affecting the extraparenchymal muscular arteries is, however, common and results in the development of coronary artery aneurysms in $20-60^{\circ}$ of cases. ${ }^{4-6}$ Death due to coronary artery thrombosis, myocardial infarction, or aneurysm rupture occurs in $1-2 \cdot 8^{\circ}$ of patients in the first three months of the illness, ${ }^{2-6}$ and there are reports of sudden death due to myocardial infarction occurring months to years after the initial illness. ?

Coronary artery aneurysms and myocardial infarction are most commonly detected after the second week of the illness and usually occur at a time when the fever and mucocutaneous manifestations are subsiding and the child appears to be convalescing. ${ }^{8}$ Thrombocytosis also occurs at this time, with the platelet count often exceeding $1000 \times 10^{9} / 1 .^{2}$ This puzzling temporal association of thrombocytosis with the development 